\title{
A MEXICAN AYTONIA
}

CONTRIBUTIONS FROM THE HULL BOTANICAL LABORATORY 2 I I

AnNa M. Stark

(WITH PLATES I-IV AND FOUR FIGURES)

To this genus ENGLer and Prantl refer six names, among which Aytonia Forst and Plagiochasma L. are most familiar in botanical literature. LEITGEB (14) made a study of Plagiochasma cordatum, $P$. intermedium, P. crenulatum (Gottsche), P. appendiculatum, and $P$. Aytonia. He gives an account of the appearance, the position, and the formation of the antheridial and archegonial receptacles, describing the order of the appearance of the archegonia and the origin of the archegonial cavity and of the involucre. $\mathrm{He}$ describes also the protective scales about the receptacles and their origin from a single row of cells, and accounts for the stalk of the receptacle as simply a dorsal outgrowth of the thallus. $\mathrm{He}$ concludes with an account of the structure of the sporogonium and its dehiscence.

The material for this investigation was collected in Mexico in I908 by Dr. W. J. G. LAND and the late Dr. Charles R. Barnes. Most of it came from the rocky sides of the deep canyon of the Rio Santiago in the state of Jalisco near Guadalajara, the rest from Carrizal in the state of Vera Cruz. The species cannot be determined definitely. Of the four Mexican forms described by GotTSCHE, it resembles most closely his Plagiochasma crenulatum, but differs in that the ventral scales reach the margin of the thallus. This Mexican form presents some variations in external appearance, and an examination of structure offers some details not covered by LEITGEB, so that it has seemed worth while to give a description of the external appearance, an account of the internal structure of the thallus and of the formation of rhizoids, a complete description of the development of the air cavities of the archegonial receptacle, and an addition to the history of development following fertilization. 


\section{Vegetative body}

The thallus (fig. I) is dorsiventral, dichotomously lobed and branched, with no groove on the dorsal side, but on the ventral side (fig. 2) a thickened median region, covered thickly with scales and rhizoids. The upper surface is green, showing purple at the edges; the ventral is light along the central region, with broad purple wings; the scales are in two rows, extending laterally from the median line, arranged alternately; they are attached along the posterior edge, lapping over those in front, and are shaped like the half of a crescent and have one or two appendages, the scales being purple and the appendages hyaline (fig. 3). Two appendages seem not to have been reported before.

The first rhizoids appear behind the first three or four pairs of scales and then occur in great abundance between the scales. They are of two kinds, pegged and smooth, the pegged appearing in bunches. They are deformed at the ends (fig. 4), but are not branched. The smooth rhizoids vary greatly in size, and frequently within the larger, smaller ones are produced (fig. 5); whether this occurs only when the larger are injured could not be determined, as most of the rhizoids were broken in collecting. The exterior rhizoids, having heavy walls, appear much older than those inside. This phenomenon is not uncommon in liverworts, often appearing in Marchantia, in which pegged rhizoids sometimes occur within plain ones. Drxon (9) also reports rhizoids within rhizoids in Lunularia cruciata, Dumortiera hirsuta, Conocephalus conicus, Anthoceros punctatus, and Marchantia polymorpha. WEINERT (I7), in a study of Marchantia and Conocephalus, says "lost rhizoids are not regenerated, but other epidermal cells grow out into new rhizoids," which is plainly the case here. A new cell or several new cells just above the layer of old rhizoids push down into the cavity of the old rhizoid.

\section{Structure}

The thallus shows the usual differentiation into thin wings of spongy tissue and a thick median region composed of close colorless tissue below and spongy chlorophyllose tissue above, the latter 
often occupying almost all of the thallus. The cavities have no regular chlorophyllose filaments, although single cells frequently project into them (figs. II and I6). In these respects Aytonia differs markedly from Marchantia, Fegatella, and Targionia.

The close tissue of the thallus is generally infested with intracellular fungi (fig. 6), filamentous, non-septate, not contracted in passing through the walls, branching irregularly, and forming sporelike bodies occasionally as vesicles within a swollen part of the main filament or in short branches. One naturally questions the origin of the fungi and the relation existing between them and the liverworts. CAvers (6) reports fungi in many liverworts, and says they are nearly always related to the soil, always occurring with humus; then he finds them traversing the rhizoids and extending into the lowest layers of the compact tissue; he thinks the fungusbearing plants are larger and thicker than others. Golenkin (I2) reports "endotropic mycorhiza" in five liverworts, and thinks they are "for storing water." NЕ̌mEc (I5) implies the entrance of the fungi through the rhizoids, and describes a pseudoparenchyma formed by them on the wall of the cells of the thallus. GarJeanne (Io) also finds them entering through the rhizoids and thinks the relation may be accidental, a case of true parasitism, or a case of true symbiosis. Miss Clapp (7) is the only one who has traced the history of the infection back to the very early stages of the sporeling. She finds fungi in as young a plant as the 4-celled stage, and states that development is hastened by the presence of the fungus. According to her, infection of rhizoids occurs from the thallus. I am inclined to think that both methods of infection of the rhizoids may happen; that the plant may become infected at any stage of development; when considerable mycelium has developed, the hyphae may grow out through the rhizoids; and when the infection occurs late the hyphae may enter through the rhizoids. In my material the fungi are only in the older parts of the thallus, and when they occur in rhizoids seem to be always growing toward the thallus (fig. 7); but in living material of $\mathrm{Mar}$ chantia and Fegatella I have found the hyphae passing out through the rhizoids. I find no "pseudoparenchyma" or balling up of hyphae, described by Ň̌mec. 
Cells secreting mucilage and resinous oils appear singly in thallus, receptacles, and scales; sometimes there is a layer of enlarged mucilage cells on the lower surface. Mucilage hairs are common about the receptacles and in the antheridial cavities. The middle lamella of the radial walls of the epidermal cells shows a tendency to become mucilaginous. Pitted cells occur in both the compact and loose tissue; they are not elongated more than other cells (fig. 8).

\section{Development}

Growth takes place by divisions of a wedge-shaped apical cell (fig. 9), as described by Leitgeb. From the lower segments scales are formed almost immediately, but rhizoids not until later. The epidermal cell giving rise to a rhizoid is often larger than the resulting rhizoid, forming a bulbous base. Division in the lower part of the thallus is more rapid than in the upper, indicated by the pulling backward of the bottoms of the air cavities. LEITGEB's theory of the origin of air cavities, as due to depressions in the surface and the upgrowth of adjacent parts, was combated by BARNES and LAND (I) and by Petsch (I6), but was upheld by Miss Black (2) in regard to Riccia Frostii. My material leaves no doubt as to their schizogenous origin (fig. Io). LEITGEB thought the spaces in Plagiochasma became partitioned by the outgrowth of cell plates. CAMPBELL (4) also says that the original air chambers become divided by the development of partial diaphragms into secondary chambers. The cavities at first are always deep and narrow, as noted by BARNES and LAND, but they soon become wide, irregular chambers by the stretching and tearing of tissues between neighboring chambers, as shown by the irregularity of the resulting surfaces and by torn cells, the tearing being due to the differences in tension between the upper and lower parts of the thallus. This leaves projecting plates of cells, appearing as filaments in section, which LEITGEB and CAMPBELL interpreted as new growth dividing the original chambers. Perhaps these plates add to their length by further growth. In fig. I I projecting filaments $a$ and $b$ are attached in the next section.

The receptacles are formed in a direct line behind the growing point. LEITGEB noted that they are not complete branches of 
the thallus, but only dorsal outgrowths. As the apical cell goes on dividing, the receptacles come to stand on the back of the thallus in a row along the median line, the antheridial appearing first, the archegonial later. Occasionally antheridial receptacles are again formed after the archegonial. Several rows of scales and mucilage hairs, dorsal outgrowths also, surround both receptacles (fig. I2).

The first indication of a receptacle is a slight elevation caused by a rapid division of the cells. My material has no early stages of the antheridial receptacle; when mature it is without a stalk and does not rise much above the surface of the thallus (fig. I2); it is cordate in shape, with the notch toward the growing point (fig. I). The surface is markedly papillate, caused by the upward growth of tissue about the antheridia, which agrees with LEITGEB's description. The deep cavities in which the antheridia stand, open to the surface by simple air pores, resembling those of the thallus except that at times there is greater projection (fig. 13). The archegonial receptacle appears in an early stage (fig. I4) as a small, bulbous outgrowth of compact, rapidly dividing cells in which are numerous chloroplasts containing starch. The cells of the under part divide radially as well as tangentially, with such regularity that a row of cells can be followed for some distance, dividing into two rows, and these two later dividing again. In the lower portion the divisions are tangential only, but the cells increase both in length and in numbers. The lower part therefore forms the stalk, while the upper part continues bulbous. The cells of the thallus below the receptacle remain compact, while those on each side form porous tissue, growing rapidly and arching up around, so that the receptacle stands in a slight depression (fig. 12) until after the archegonia are mature. Fertilization probably takes place very easily. Later the stalk elongates and lifts the receptacle above the surface; it may attain the length of 3 or $4 \mathrm{~mm}$.

Air cavities appear early in the developing receptacle, starting about the same time as the archegonia, the origin being like that of the cavities of the thallus. The split occurs first at the juncture of epidermal and hypodermal cells (fig. ro), between cells of different segments of the apical cell, cells derived from the same segment 
remaining attached for a longer time. The split may extend almost immediately to the surface (fig. I5) or be delayed until the formation of the pore (fig. I6). The structure of the pore is more elaborate than in cavities of the thallus, as noted by CAMPBELL (3) in archegonial receptacles in general. The cells destined to form the margin become evident by an increase in size (fig. I5); segments are cut off from the inner side, generally by oblique walls (fig. I 7); more divisions occur until $3-5$ rows of cells form a ring extending down into the enlarging cavity (fig. I8); then segments are cut off from the outer part of the cells of the margin, walls being again oblique, followed by another division, so that a projecting ring of cells three layers thick is formed (fig. I9). The cells of the last row shrink and become highly cutinized, giving a beaklike effect in section (fig. 20), as noted by Deutsch (8) in Targionia. I find no such thickening of the walls as LEITGEB shows in surface view, but only such an effect as appears in fig. $2 \mathrm{I}$, taken from the older part of the thallus. Of course my material may have grown under conditions entirely different from his. With the increase in size of the cavity the pore spreads and becomes a barrel-like opening. The development is not complete until fertilization has taken place and the receptacle has increased greatly in size.

\section{Sex organs}

The development of the antheridium is probably such as is general in the Marchantiaceae, but my material has no early stages. Occasionally the antheridium has a long stalk; less frequently the upper end is beaked; but the usual form is short-stalked and conical. About the antheridium are glandular hairs, and among the cells forming the wall of the pit are mucilage cells, the secretions from which probably assist the dispersal of the sperms. The antheridia are produced in acropetal succession, so that the younger are toward the apex (fig. I2).

The archegonia are reported by CAMPBELL (5) to be 3 or 4 in number, the one to the rear developing first, the lateral ones next, and the one in front last. My material confirms the statement in general, but 5 archegonia may occur. They begin development near the top of the receptacle (fig. I4), but are carried under 

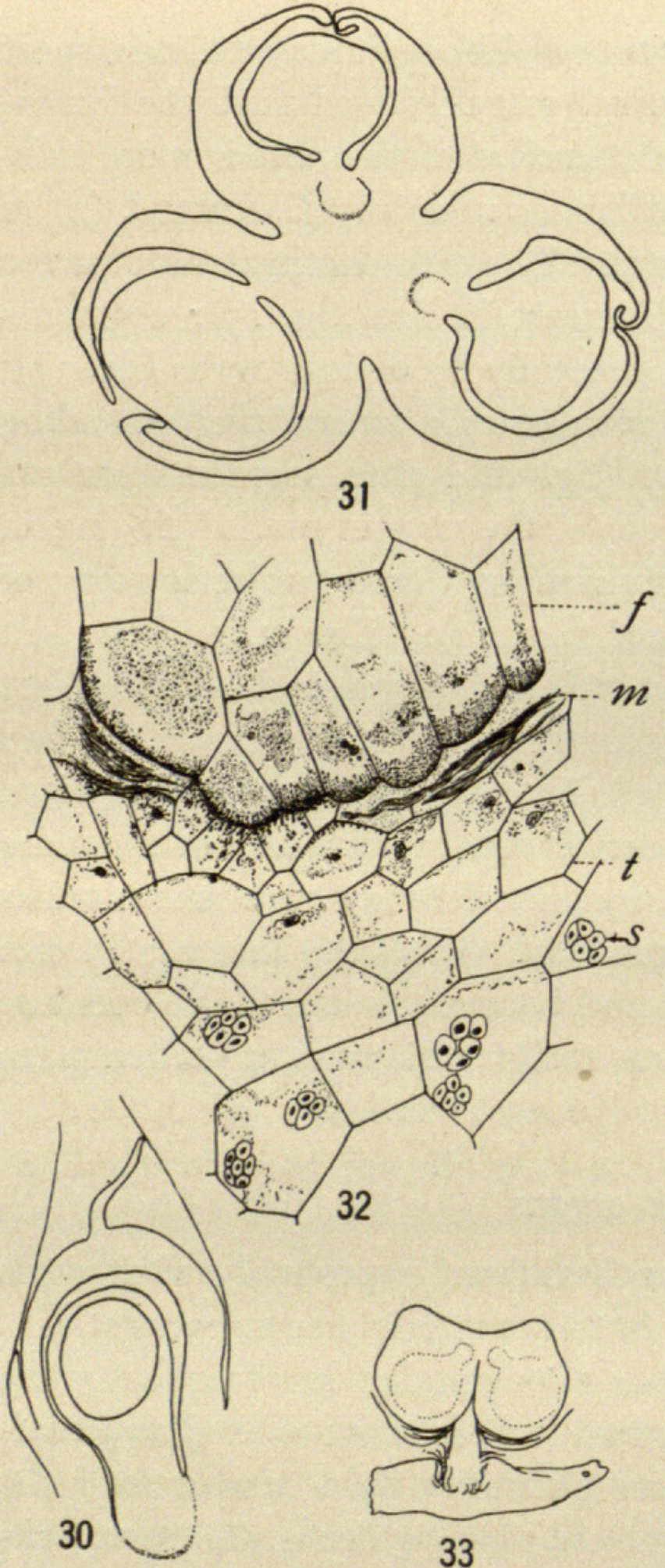

FIGS. 30-33.-Fig. 30, vertical section of a young sporogonium within the calyptra, $\mathrm{X}_{32}$; fig. $3 \mathrm{I}$, transverse section of an archegonial receptacle, cutting obliquely through three sporogonia within their involucres which show the vertical opening; fig. 32 , section through the region of contact of foot and thallus ( $f$, foot; $t$, thallus; $m$, mucilaginous remains; $s$, starch), $\times 667$; fig. 33 , sketch of archegonial receptacle indicating the position of the sporogonia. by the rapid growth of the tissue above (fig. I2). The stages of development that appear indicate the sequence usually given. In 1897 GaYet (II) claimed that he had demonstrated in Marchantia, Preissia, and other Hepaticae, that division in the cover cell by intersecting quadrant walls does not take place until a late period, and that before it occurs repeated segments are cut off its lower face, which add to the length of the neck. Figs. 24, 26, and 27 leave no room for doubt that in Aytonia a quadrant division occurs early in the cover cell, and that the neck lengthens by divisions lower down. The neck cells divide simultaneously until 8 cells are formed (fig. 27), showing greater regularity than is commonly reported. The egg has a large nucleus but no "receptive spot"; it fills the cavity of the venter up to the time that fertilization is to take place; then the cells forming the wall of the venter divide rapidly, parallel to the surface of the egg; at the same time there is an increase in the size of the cavity or 
else the egg shrinks, so that there is considerable space between the egg and the upper part of the venter. The egg then generally contains large, perfectly spherical globules that stain deeply red with safranin; the shape suggests a fatty food substance. The breaking down of the canal cells leaves the egg invested with a great amount of striated mucilaginous substance which often fills more than half the venter (fig. 28). When the first division of the embryo occurs, all the cells of the venter have divided. Growth continues in the stalk, the venter, and the lower part of the neck until an extraordinary amount of tissue is developed about the embryo and the neck is greatly elongated, curving up above the cushion of the receptacle (fig. 29).

\section{Sporogonium}

The embryo develops in the usual way, beginning with a transverse wall. At first the seta appears as of considerable length when compared to the whole body (fig. 30), but later the capsule and foot develop more rapidly, so that the seta comes to be inconspicuous (figs. $3 \mathrm{I}$ and 33 ). The foot is well developed as an absorbing organ, the cells next to the thallus being large and slightly rhizoidal in shape. Just within the walls of these cells and of the adjoining cells of the thallus there is a granular deposition, probably related to the passage of nutrient material from the thallus to the parasitic sporogonium. The cells of the thallus respond to the invasion of the foot by dividing, as is shown by the cells nearest the foot being smaller than elsewhere. As the cells break down, a mucilaginous deposit remains, marking the limit between foot and thallus (fig. 32). As the sporogonium matures, the starch contained in the cells of the thallus near the foot disappears, and in all the cells of the receptacle it is scantier than in earlier stages.

The history of the development of the capsule and of the involucre, resembling the valves of a clam shell, has been described by LeItgeB. It might be added that a few cells at the base of the capsule remain sterile, but there is no regular elaterophore. 


\section{Summary}

I. Two appendages may be present on the ventral scales.

2. Rhizoids are absent among the first pairs of ventral scales. them.

3. Old rhizoids are often replaced by new ones that form within

4. Fungi are prevalent in the compact tissue of the thallus. They enter through the rhizoids and may also pass out through them. No "pseudoparenchyma" was found.

5. The secretion of mucilage seems to have nothing to do with the "protection" of the growing point, but to be most pronounced about the egg and the antheridia.

6. Pitted cells show no tendency to become trachea-like.

7. The origin of air chambers in the thallus and receptacles is schizogenous. The horizontal increase in the size of the chambers is due to a tearing of the tissues. The pore of the chambers of the thallus and of the antheridial receptacle is simple, but that of the archegonial receptacle has an elaborate margin.

8. The development of the sex organs follows the Marchantiales type. The archegonia form early in the history of the receptacle and parallel the increase in size of the receptacle by great increase in length of the neck. Following fertilization an exceedingly massive venter is developed about the embryo.

9. Five archegonia may begin to develop on one receptacle, but no more than three come to maturity.

I0. The condition of the cells of the foot and of the adjacent parts of the thallus indicate the parasitic nature of the sporogonium. No elaterophore appears.

Most cordial thanks are due Dr. W. J. G. LAND, who furnished the material for this study and followed the work with interest and encouragement.

Mount Holyoke College

\section{LITERATURE CITED}

r. BARNES, C. R., and LAND, W. J. G., Bryological papers I. The origin of air chambers. Вот. GAZ. 44: 197-213. 1907.

2. Black, Caroline A., The morphology of Riccia Frostii. Ann. Botany 27:511. I9I3. 
3. Campbell, D. H., The structure and development of mosses and ferns. New York. 1905 (p. 42).

4. - op. cit. p. 48.

5. - op. cit. p. 56 .

6. Cavers, F., On saprophytism and mychorhiza in Hepaticae. New Phytol. 2:30-35. 1903.

7. Clapp, Grace L., The life history of Aneura pinguis. Bot. Gaz. 54: I77I93. I9I2.

8. Deutsch, H. D., A study of Targionia hypophylla. Bot. GAz. 53:492-503. I9I2.

9. Drxon, H. H., Notes from the Botanical School of Trinity College, Dublin. 14 (p. I4r).

10. Garjeanne, Anton J. M., Úber die Mykorrhiza der Lebermoose. Beih. Bot. Centralbl. 15:470-482. 1903.

II. Gayet, L. A., Recherches sur le développement de l'archegone chez les Muscinées. Ann. Sci. Nat. Bot. 8: 161-258. 1897.

12. Golenkin, M. I., Die Mykorrhiza-ähnlichen Bildungen der Marchantiaceen. Flora 90:209. 1902.

13. Gotrsche, C. M., De mexikanske Levermosser. Det Kongelige Danske Vidensk. Selsk. Skrift. 6:99-382. I867.

14. Leitgeb, H., Untersuchungen über die Lebermoose. Die Marchantieen 5:6. $1874-1882$.

15. NĚMEc, B., Die Mykorrhiza einiger Lebermoose. Ber. Deutsch. Bot. Gesells. 17:311. I899.

r6. Petsch, W., Entwickelungsgeschichte des vegetativen Thallus, insbesondere der Luftkammern der Riccien. Flora 103:347-384. I9Ir.

I7. WeINERT, H., Untersuchungen über Wachstum und tropistische Bevegungserscheinungen der Rhizoiden thallöser Lebermoose. Bot. Zeit. 67:201-230. 1909.

\section{EXPLANATION OF PLATES I-IV}

FIG. I.-Sketch of monoecious thallus, dorsal view.

FIG. 2.- Sketch of thallus, ventral view.

FIG. 3.-Sketch of ventral scales with appendages.

FIG. 4. - Sketch of rhizoids; $X_{470}$.

FIG. 5.-Longitudinal section of an old rhizoid with a new one developing within.

FIG. 6.-Section of compact tissue by the thallus with fungal hyphae passing through the walls and destroying the protoplasm; $X_{45}$.

FIg. 7.-Fungal hyphae entering a thallus through a rhizoid.

FIG. 8.- Surface view of a pitted cell; $\times 687$.

FIG. 9.-Vertical longitudinal section of a thallus through the apical cell, showing the origin of ventral scales $(s)$ and air chambers $(a$ and $b) ; \times 375$. 
Fig. Io.-Vertical section of developing air cavities in an archegonial receptacle; $\times 750$.

FIG. II.-Vertical section of an air pore of the thallus; $\times 667$.

Fig. I2.- Vertical longitudinal section of a thallus with two archegonial receptacles and one antheridial.

FIG. 13.-Vertical section of a pore in an antheridial receptacle.

Fig. I4.-Vertical section of an early stage of an archegonial receptacle; $\times 67$.

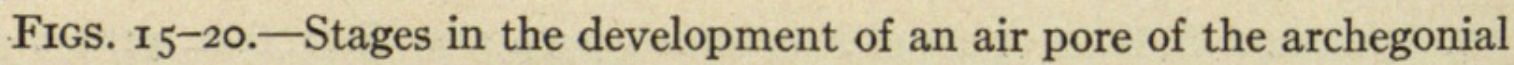
receptacle.

Fig. 21.- Surface view of an air pore of the thallus.

FIGS. 22-27.-Stages in the development of the archegonium before the formation of the egg; fig. 25 shows also the origin of a scale and of the involucre $(i)$.

Fig. 28.-Vertical section of a venter after fertilization; $n$, nucleus; $g$, spherical globule; $\times 667$.

FIG. 29.-Vertical section of an archegonium inclosing a young embryo; $\times 470$. 


\section{$2 \mathrm{BHL}$ Biodiversity Heritage Library}

Starr, Anna M . 1916. "A Mexican Aytonia." Botanical gazette 61(1), 48-58. https://doi.org/10.1086/331714.

View This Item Online: https://www.biodiversitylibrary.org/item/109212

DOI: https://doi.org/10.1086/331714

Permalink: https://www.biodiversitylibrary.org/partpdf/223730

\section{Holding Institution}

Missouri Botanical Garden, Peter H. Raven Library

\section{Sponsored by}

Missouri Botanical Garden

\section{Copyright \& Reuse}

Copyright Status: Public domain. The BHL considers that this work is no longer under copyright protection.

This document was created from content at the Biodiversity Heritage Library, the world's largest open access digital library for biodiversity literature and archives. Visit BHL at https://www.biodiversitylibrary.org. 